Leger, L., Lenriot, J.P. \& Lemaigre, G. (1968) L'hypertension et la stase portales segmentaires dans les pancréatites chroniques. Journal de Chirurgie (Paris), 95, 599.

McCurdy, D.K., Frederic, M. \& Elkington, J.R. (1968) Renotubular acidosis due to amphotericin B. New England Journal of Medicine, 278, 124.

NeW, P.S. \& Wells, C.E. (1965) Cerebral toxicity associated with massive intravenous penicillin therapy. Neurology, 15, 1053.

Newcomer, V.D., Sternberg, T.H., Wright, E.T. \& REISNER, R.M. (1959) Current status of amphotericin B in the treatment of systemic fungus infections. Journal of Chronic Disease, 9, 353.

Pepys, J., FaUX, J.A., Longbottom, J.L., McCarthy, D.S. \& HARGREAVES, F.E. (1968) Candida albicans precipitins in respiratory disease in man. Journal of Allergy, 41, 305.

SAlTER, W. \& ZinNemaN, H.N. (1967) Bacteremia and candida septicaemia. Minnesota Medicine, 50, 1489.

Schindler, S.C., Schaefer, J.W., Hull, D. \& Griffen, W.O. JR. (1970) Chronic pancreatic ascites. Gastroentero$\log y, 59,453$.

Schwarz, R. \& DAMEsheK, W. (1960) The effects of 6mercaptopurine on homograft reaction. Journal of Clinical Investigation, 39, 952.
StaAl, A., Mechelse, K. \& De Leeuw, B. (1963) Neurologische complicatie by toediening van een fungicied antibioticum. Nederlands Tïdschrift voor Geneeshuade, 107, 2276.

Stallybrass, F.C. (1964) Candida precipitins. Journal of Pathology and Bacteriology, 87, 89.

UTZ, J.P. \& TREGER, A. (1959) The current status of chemotherapy of systemic fungal diseases. Annals of Internal Medicine, 51, 1220.

VINCE, S. (1959) Generalised endogenous mycoses in childhood. Medical Journal of Australia, 46, 145.

WINNER, H.I. (1955) A study of Candida albicans agglutinins in human serum. Journal of Hygiene, 53, 509.

Winner, H.I. (1966) Symposium on Candida Infections (Ed. by $\mathbf{H}$. I. Winner and R. Hurley). Livingstone, Edinburgh and London.

WinNer, H.I. \& HuRley, R. (1964) Candida albicans. Churchill, London.

ZIMMERMAN, L.E. (1955) Fatal fungal infections complicating other diseases. American Journal of Clinical Pathology, 25, 46.

\title{
Myopathy from E-aminocaproic acid: a second case
}

\author{
JOHN R. BENNETT \\ M.D., M.R.C.P.
}

\section{Gastro-Intestinal Unit, Hull Royal Infirmary, Kingston-upon-Hull}

EPSILON-AMINOCAPROIC acid (EACA) is an antifibrinolytic agent which inhibits the activation of plasminogen to plasmin (Alkjaersig, Fletcher \& Sherry, 1959). Its main therapeutic use is in the arrest of bleeding when abnormal fibrinolytic mechanisms are present (Sweeney, 1965). Because of suggestions that fibrinolysis in the colonic mucosa might be abnormal in ulcerative colitis (Kwaan, Cocco \& Mendeloff, 1964). EACA has been used to control excessive bleeding in this condition with apparent success (Nilsson, Anderson \& Bjorkman, 1966; Salter \& Read, 1970). There is a high incidence of side-effects from EACA, such as nausea, diarrhoea, giddiness and faintness, but few serious toxic effects have been encountered other than possible thrombosis. However, one patient who developed extensive muscle necrosis during EACA treatment for periodic oedema has been described (Korsan-Bengsten et al., 1969) and this report is of myopathy due to EACA in a patient with ulcerative colitis.

\section{Case report}

A male clerk developed frequent, watery, bloodstained diarrhoea at the age of 32, and initially improved on self-administered herbal treatment. He was first seen in relapse after 2 years' illness when he was acutely ill, with an oral temperature of $104^{\circ} \mathrm{F}$. There was oral ulceration and sigmoidoscopy showed the rectal mucosa to be thickened, granular, friable and bleeding. Barium enema was normal and initial investigations gave these results: $\mathrm{Hb}, 12 \cdot 2 \mathrm{~g} / 100 \mathrm{ml}$; serum sodium, $133 \mathrm{mEq} / 1$; potassium, $3.9 \mathrm{mEq} / 1$; chloride, $100 \mathrm{mEq} / \mathrm{l}$; serum mucoproteins, 187 $\mathrm{mg} / 100 \mathrm{ml}$. Microscopy and culture of faeces revealed no parasites or pathogenic bacteria.

Treatment with intramuscular corticotrophin gel $80 \mathrm{U}$ daily, oral sulphasalazine $1 \mathrm{~g}$ 6-hourly, hydrocortisone enemata $100 \mathrm{mg}$ daily, with intravenous fluid and electrolyte replacement (1 September 1970) caused early improvement and he kecame afebrile within 4 days. Nevertheless, diarrhoea with copious visible bleeding persisted and after 2 weeks' treatment the rectal mucosa still looked acutely inflamed sigmoidoscopically. EACA (as Epsikapron syrup) $6 \mathrm{~g}$ every $6 \mathrm{hr}$ was commenced on 14 September, and a week later (21 September) azathioprine $100 \mathrm{mg}$ daily was added to his treatment; subsequently both the frequency of diarrhoea and quantity of bleeding diminished. Corticotrophin was gradually withdrawn and stopped on 16 October, but he remained on 
EACA, azathioprine, sulphasalazine and methyl cellulose.

On 16 November 1970 he was seen because of propressive weakness of his legs which he first noticed about 2 weeks earlier. Examination showed weakness of all leg muscles, particularly the proximal groups, and weak anterior abdominal musculature, while the shoulder-girdle muscles were only slightly affected. Azathioprine, EACA and sulphasalazine were stopped, but he continued to use hydrocortisone enemata. The weakness started to improve immediately. An electromyogram (EMG) of quadriceps femoris and gastrocnemius showed a reduced interference pattern and bursts of giant potentials up to $10 \mathrm{mV}$. Two weeks later (3 December) the left deltoid was examined by EMG and showed many polyphasic action potentials, most between 2 and $4 \mathrm{msec}$ duration. The mean potential duration was 2 msec. suggesting a myopathy (Dr M. Rawson). Serum creatine phosphokinase (SCPK) on 16 November was $1360 \mathrm{mU} / \mathrm{ml}$ (normal 50) falling gradually to reach normal on 2 December.

As it was possible that any of the three drugs under suspicion might be required to treat him in the future it was decided to challenge him with them serially and the patient consented after full explanation. Azathioprine $100 \mathrm{mg}$, EACA $4 \mathrm{~g}$, and sulphasalazine $2 \mathrm{~g}$ were given by mouth consecutively with 2 days between; none caused pyrexia, weakness or rise in serum creatine phosphokinase or serum aspartate transaminase. EACA was then given $4 \mathrm{~g}$ 6-hourly for six doses without causing any abnormality.

Despite maintenance therapy with prednisolone enemata his procto-colitis relapsed in early March 1971. Systemic corticotrophin, milk-free diet, sulphasalazine $1 \mathrm{~g}$ 6-hourly, and twice daily hydrocortisone enemata produced no significant benefit, and on 29 March 1971, azathioprine $100 \mathrm{mg}$ daily was added. No muscular weakness was noted and twice weekly estimations of SCPK and SGPT showed no rise. By 4 April daily faecal weights had fallen from $300-500 \mathrm{~g}$ to $100-200 \mathrm{~g}$ with single daily evacuations and no rectal bleeding. Sigmoidoscopic appearances also improved. Corticotrophin was withdrawn during May 1971, but the other drugs were continued until November 1971 without clinical or biochemical evidence of myopathy.

\section{Discussion}

Myopathy is not a recognized complication of ulcerative colitis and circumstantially it seems likely to have been a toxic effect of a drug. Proximal myopathy due to corticosteroids is well recognized (British Medical Journal, 1962) though usually in patients on high doses. This patient was not having ACTH at the time the myopathy developed, though he was having hydrocortisone alcohol enemata.
Corticosteroids are absorbed when administered rectally (Nabarro et al., 1957; Sampson \& Brooke, 1963; MacDougall, 1963) but the quantities are not likely to be sufficient to produce myopathy - certainly this complication has not been reported. Further, the myopathy improved while he continued with the enemata, and they have been used since with no recurrence of weakness.

Sulphasalazine, azathioprine and EACA were suspected, but none produced detectable abnormalities after brief challenge courses. However, the first two have since been used for clinical reasons without myopathy recurring, and by exclusion it is probable that EACA was the provocative agent. In the only other reported instance of EACA myopathy (KorsanBengsten et al., 1969) myopathy developed after 5 weeks of commencing EACA $30 \mathrm{~g}$ daily, though 'orthostatic reactions' had been noted earlier. After recovery EACA was given again at the same dosage with earlier rhinitis, facial oedema and orthostatic reactions, but muscle pains with raised SGPT and SCPK occurred only after 7 weeks treatment. In our patient weakness was noticed about 6 weeks after commencing EACA, and the long time lag presumably explains the failure of a single day's treatment to cause even changes in serum enzyme levels.

In the other reported case muscle biopsy showed 'hyaline degeneration breaking down to necrosis' similar to Zenker's degeneration seen in typhus, diphtheria, Weil's disease and anaphylaxis. The authors offer no satisfactory explanation of the myopathy, and none is evident from our own observations.

It is recommended that, whenever EACA is given for more than a month, patients should be warned to report any muscular weakness, and serial measurements of SCPK should be performed.

\section{Acknowledgments}

I am most grateful to Dr Malcolm Rawson and the staff of the Neurophysiology Department, Hull Royal Infirmary for the electromyograms, and to Mr J. Parkes for the biochemical tests.

\section{References}

Alkjaersig, N., Fletcher, A.P. \& Sherry, S. (1959). Eaminocaproic acid: an inhibitor of plasminogen activation Journal of Biological Chemistry, 234, 832.

British Medical Journal (1962) Muscle weakness from corticosteroids, 2, 110.

Korsan-Bengsten, K., Ysander, G., Blohme, G. \& Tibblin, E. (1969) Extensive muscle necrosis after longterm treatment with aminocaproic acid in a case of hereditary periodic oedema. Acta medica scandinavica, 185, 341.

KwaAn, H.C., Cocco, A. \& Mendeloff, A.I. (1964). Histologic demonstration of plasminogen activation in rectal biopsies from patients with ulcerative colitis. Journal of Laboratory and Clinical Medicine, 64, 877.

MacDougall, I. (1963) Treatment of ulcerative colitis with rectal steroids. Lancet, i. 826. 
Nabarro, J.D.N., Moxham, A., Walker, G. \& Slater J.D.H. (1957) Rectal hydrocortisone. British Medical Journal, 2, 272.

Nilsson, I.M., Anderson, L. \& Buorkman, E. (1966) Epsilon-aminocaproic acid as a therapeutic agent based on 5 years' clinical experience. Acta medica scandinavica, Suppl. 448.
SAlter, R.H. \& ReAD, A.E. (1970) Epsilon-aminocaproic acid therapy in ulcerative colitis. Gut, 11, 585.

Sampson, P.A. \& BROOKe, B.N. (1963). Absorption of hydrocortisone from the large bowel. Lancet, i, 701 .

SWEENEY, W.M. (1965) Aminocaproic acid, an inhibitor of fibrinolysis. American Journal of Medical Sciences, 249, 576.

Postgraduate Medical Journal (July 1972) 48, 442-445.

\title{
Eosinophilic leukaemia
}

\author{
N. IsLAM \\ M.B., F.R.C.P.(Ed)., F.C.P.S. \\ A. K. M. B. KARIM \\ M.B., B.S., D.T.M.\&H., M.R.C.P.(Glas. \& Edin).
}

\author{
K. M. RAHMAN \\ M.B., B.S., M.Sc., D.B., D.Path., M.R.C.Path.
}

Institute of Postgraduate Medicine, Dacca-2, Bangladesh

MARKED leucocytosis with eosinophilia in the peripheral blood can occur due to various causes which may be either benign or malignant (Islam, 1964). It is therefore very difficult at times to establish the diagnosis of eosinophilic leukaemia.

In spite of earlier doubt about the existence of eosinophilic leukaemia as a distinct entity (Dameshek \& Gunz, 1964) it is now established that it does exist. According to Chen \& Smith (1960) less than thirty cases were reported by 1957 . Wintrobe (1967) states that 100 cases have been described of which Bentley et al. (1961) could accept only twenty as true cases of eosinophilic leukaemia. These authors also reported a case of their own with their review. Evidently true cases of eosinophilic leukaemia are extremely rare.

\section{Case report}

F.A. 11 years, a school student from Dacca came to one of us (N.I.) on 2 November 1968 with a history of cough with scanty expectoration, fever $\left(100^{\circ} \mathrm{F}\right)$ and vague abdominal discomfort for the previous 3 weeks.

On examination there was no abnormality except a few scattered rales on both sides of the chest. A chest $\mathrm{X}$-ray was not abnormal while the blood count showed a leucocyte count of $100,000 / \mathrm{mm}^{3}$ with $80 \%$ eosinophils. A tentative diagnosis of tropical eosinophilia was made. Diethylcarbamazin $400 \mathrm{mg}$ a day for 2 weeks was advised. Three weeks later on reexamination the child showed no sign of improvement but was anaemic and presumably had lost some weight. Axillary lymph nodes were enlarged and there was sternal tenderness. Liver was $25 \mathrm{~cm}$ and spleen $5 \mathrm{~cm}$ below the costal margins. A week later he was admitted under one of us (N.I.) in the Institute of Postgraduate Medicine, Dacca (4 December 1968) when an infiltrate in the right fundus was discovered. His total leucocyte count was found to be $190,000 /$ $\mathrm{mm}^{3}$ with $96 \%$ eosinophils. Filarial complement fixation test (FCFT) was negative. A diagnosis of eosinophilic leukaemia was made. A lymph node was removed and sent to Professor C. V. Harrison of the Royal Postgraduate Medical School, London. Meanwhile therapy was started with prednisone and 6-mercaptopurine which was continued for about 4 weeks followed by Myleran and parenteral hydrocortisone. Microscopically the lymph node was found to retain its normal architectural pattern. Scattered through the node there were numerous eosinophil granulocytes. The majority of these were fully differentiated leucocytes and the rest were eosinophil myelocytes which Professor Harrison thought was consistent with the clinical diagnosis of eosinophilic leukaemia.

On request from his relations the boy was then sent to the Royal Postgraduate Medical School where he was admitted on 5 February 1969.

\section{Investigations}

Peripheral blood. WBC, $21,000 / \mathrm{mm}^{3}$; neutrophils, $12 \%$; eosinophils, $72 \%$; lymphocytes, $15 \%$; monocytes, $1 \%$; Hb, $7 \mathrm{~g} / 100 \mathrm{ml}$; reticulocytes, $1 \%$; PCV, $23 \%$; MCHC, $30 \%$; platelets, $63,000 / \mathrm{mm}^{3}$. 